\title{
LEUKOTRIENE C4 SYNTHASE AND LEUKOTRIENE RECEPTOR-1 GENES POLYMORPHISM AMONG ATOPIC ASTHMATIC PATIENTS
}

\author{
Heba M. Kadry, Amal H. Atta, Mostafa K. Sultan and Nagwa A. El-Baz \\ Medical Microbiology and Immunology, Faculty of Medicine, Zagazig University, Egypt
}

Received 2014-03-09; Revised 2014-03-26; Accepted 2014-05-05

\begin{abstract}
Asthma is a complex polygenic disease in which Cysteinyl Leukotrienes (Cys-LTs) are a potential risk factors causing airway inflammation and remodeling, which are characteristics of asthma. The polymorphisms in the leukotriene $\mathrm{C} 4$ synthase $-444 \mathrm{~A} / \mathrm{C}$ and cysteinyl leukotriene receptor $1927 \mathrm{~T} / \mathrm{C}$ genes has been implicated in susceptibility to asthma. The objective of this study was to analyse two different polymorphisms, LTC4S-444 A/C and Cys-LTR1 927 T/C single nucleotide polymorphism and to determine whether there is an association between these polymorphisms and asthma development. The study included two groups ( 30 asthmatics and 30 healthy controls). They were genotyped for the LTC4S$444 \mathrm{~A} / \mathrm{C}$ and CysLTR1 $927 \mathrm{~T} / \mathrm{C}$ polymorphisms by PCR-RFLP. Their total serum IgE levels and urinary LTE4 levels were measured by Enzyme Linked Immunosorbent Assay (ELISA). IgE levels and urinary leukotriene E4 levels were higher in patient group than control group. The genotype and allele frequencies of both $L T C 4 S-444 A / C$ and CysLTR1 927 T/C polymorphism were not significantly different between asthmatic patients and control group. While urinary leukotriene E4 levels were significantly higher in variant types of LTC4 synthase (AC and CC) compared to wild type (AA). This study does not support the role of these polymorphisms in genetic susceptibility to asthma but provide an evidence for a functional role of LTC4 synthase-444 A/C polymorphism on Cys-LT synthesis.
\end{abstract}

Keywords: CysLTs, LTC4S, CysLTR1, Asthma, Polymorphism

\section{INTRODUCTION}

Bronchial asthma is a chronic inflammatory disorder of the airways characterized by airway hyper-responsiveness, reversible airflow limitation and recurrent episodes of wheezing, shortness of breath, chest tightness and cough (GINA, 2011). Bronchial asthma is prevalent worldwide, especially in developed countries. The prevalence of asthma has rapidly increased over the last few decades and there are an estimated 300 million sufferers worldwide, a total that is expected to rise dramatically over the next 15-20 years (Jenna and Clare, 2010).

Airway inflammation is a hallmark of asthma and is caused by the release of cytokines and mediators from a variety of cells. Cysteinyl leukotrienes (Cys-LTs) are key lipid mediators that mediate several steps in the pathophysiology of chronic asthma, including bronchoconstriction, inflammatory cell recruitment, vascular leakage, mucus hypersecretion and airway remodeling (Celine et al., 2012). The synthesis of CysLTs in asthmatic individuals is increased, as shown by its increased secretion in urine, exhaled breath condensate and sputum (Austen et al., 2009). LTC4 synthase (LTC4) is the critical enzyme in formation of Cys-LTs (i.e., LTs C4, D4 and E4) from LTA4 through the addition of glutathione group in position C-6 (Hiromichi et al., 2011).

LTC4S is an $18 \mathrm{kDa}$ integral membrane protein with a cellular distribution including eosinophils, basophils, mast cells, platelets and monocytes. The gene encoding LTC4S is located on long arm of chromosome 5q35 (Niegowski et al., 2014). Among the genetic variants described for $L T C 4 S$, polymorphism- $444 \mathrm{~A} / \mathrm{C}$ is located 
in the promoter region of the gene. This polymorphism would affect the binding sites of the transcription factors, modifying the expression of LTC4S. An increase in the prevalence of the $C$ allelic variant has been reported in adult patients with asthma (Sampson et al., 2000), although other studies have failed to confirm this association (Kang et al., 2011; Ingrid et al., 2012).

Pharmacological studies have determined that CysLTs activate at least two types of receptors, designated CysLTR1 and CysLTR2 (Duroudier et al., 2009), CysLTR1 is expressed in airway smooth muscle cells, tissue macrophages, monocytes and eosinophils. The biological actions of Cys-LTs probably occur because of binding to these receptors on the surface of target cells (Okunishi and Peters-Golden, 2011).

The association between CysLTR1 variation and risk of asthma is biologically plausible. Although SNP 927 $C / T$ does not cause any change in amino acid sequence, it remains likely that the nucleotide substitution at 927 $C / T$ might affect the efficiency of CysLTR1 mRNA processing and stability (Hong et al., 2009).

\subsection{Objectives}

This study aimed to analyse polymorphisms in LTC4S-444 A/C and CysLTR1 927 T/C genes and their interaction and to determine whether there is an association between these polymorphisms and asthma development in Egyptian asthmatic patients.

\section{MATERIALS AND METHODS}

This case control study was conducted on 30 Egyptian patients clinically diagnosed as asthmatic patients and 30 healthy controls. The patient group included 15 males and 15 females with age ranged from 13 to 50 years with a mean age of $32.1 \pm 7.9$ years. None of the patients had ever received immunotherapy nor was under anti-leukotrienes drugs. The control group included 13 males and 17 females with age ranged from 18 to 43 years with a mean age of $28.6 \pm 7.3$ years. None of the healthy controls reported any history of acute or chronic medical problems. This work was conducted in Microbiology and Immunology Department, the Allergy and Immunology Unit of Microbiology and Immunology Department, Faculty of Medicine, Zagazig University during the period from 2011 to 2013.

All groups were subjected to the following:

- Full medical history taking

- Intradermal skin test (patients only)
- Quantitative determination of total serum IgE levels by ELSA (Pishtaz Teb Diagnostics, Iran)

- Quantitative determination of urinary leukotriene E4 levels by ELSA (Cusabio biotech co., USA)

- Determination of creatinine levels in urine for correction of total urine concentration

- $\quad$ Single Nucleotide Polymorphism (SNP) genotyping by polymerase chain reaction-restriction fragment length polymorphism (PCR-RFLP) for detection of LTC4-444 A/C and CysLTRI $927 \quad T / C$ genes polymorphism

- DNA extraction from whole blood taken on EDTA using QIAamp Blood Genomic DNA Mini (ROCHE, Germany) according to manufacture's instructions

- Detection of polymorphism at LTC4 synthase-444 A/C

\subsection{Amplification}

PCR reactions were performed using Taq PCR beads (Bioron Beads, Germany), the oligonucleotide primers were, forward 5' TCC ATT CTG AAG CCA AAG GC 3' and reverse 5' GTG ACA GCA GCC AGT AGA GC 3'(New England Biolabs Inc., USA). Reaction mixtures were done in a DNA heated lid thermal cycler (Biometra Ltd, Germany). PCR conditions for LTC4S were, $5 \mathrm{~min}$ for initial denaturation at $94^{\circ} \mathrm{C} ; 30$ cycles at $94^{\circ} \mathrm{C}$ for 30 sec for denaturation, $30 \mathrm{sec}$ at $59^{\circ} \mathrm{C}$ for annealing and 1 min at $72^{\circ} \mathrm{C}$ for extension, followed by $10 \mathrm{~min}$ at $72^{\circ} \mathrm{C}$ for final extension (Mary-Anne et al., 2004).

\subsection{Restriction Fragment Length Polymorphism}

After amplification, PCR products were digested by the restriction endonuclease MspI (New England Biolabs). The following components were in $20 \mu \mathrm{L}$ tube reaction, $5 \mu \mathrm{L}$ of pyrogen free water, $2 \mu \mathrm{L}$ of $10 \mathrm{X}$ reaction buffer, $3 \mu \mathrm{L}$ of the restriction enzyme containing $4 \mathrm{U}$ of the enzyme and $10 \mu \mathrm{L}$ PCR products. The components were mixed gently, spin down briefly and then incubated at $37^{\circ} \mathrm{C}$ for $4 \mathrm{~h}$.

\subsection{Detection}

The digestion products were analyzed on $2 \%$ agarose gel stained with ethidium bromide solution $\left(1 \mathrm{mg} \mathrm{mL}^{-1}\right)$. The enzyme digest the amplicon to a common $446 \mathrm{bp}$ fragment and gives a fragment of $117 \mathrm{bp}$ for $A$ allele, 2 fragments of 85 and 32 bp bands for $C$ allele. 3 fragments of 117, 85 and $32 \mathrm{bp}$ for heterozygous person (Fig. 1).

Detection of polymorphism at CysLTR1 927 T/C. 


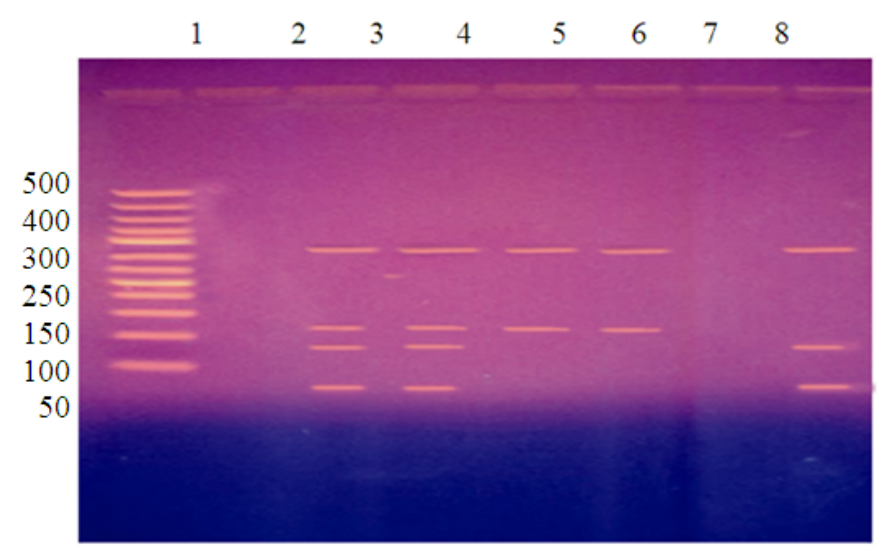

Fig. 1. Gel electrophoresis for LTC4 synthase Lane 1: Shows 50 bp MW marker. Lane 2: Shows negative control.Lane 5 and 6: Show two bands of 446 bp and 117 bp indicating LTC4S (A/A) genotype. Lanes 8: Shows three bands of 446, 85 and 32 bp indicating LTC4S $(C / C)$ genotype. Lane 3 and 4: Show four bands of 446, 117, 85 and 32 bp indicating LTC4S (C/A) genotype.bp indicating $L T C 4 S(C / C)$ genotype.Lane 3,7: Show four bands of 446, 117, 85 and 32 bp indicating $L T C 4 S(C / A)$ genotype

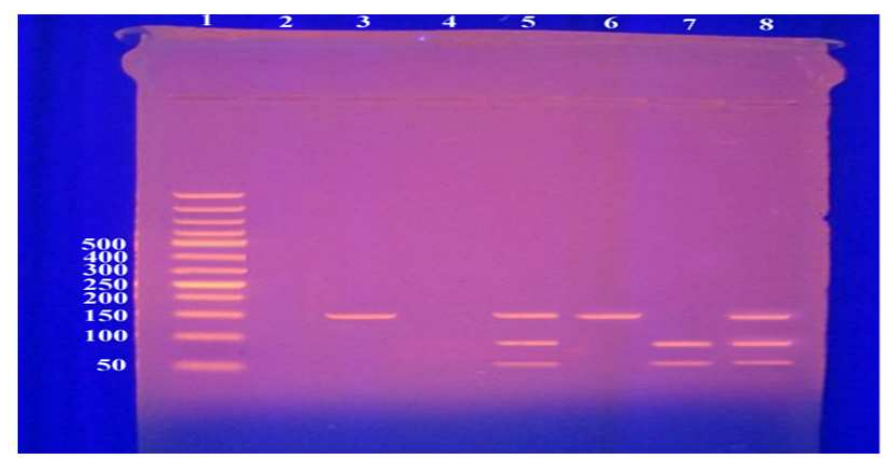

Fig. 2. Gel electrophoresis of CysLTR1 Lane 1: Shows 50 bp MW marker. Lane 2: Shows negative control. Lane 3 and 6: Shows a single band of 150 bp indicating CysLTR1 (T/T) genotype. Lanes 7: Show two bands of 97 and 53 bp indicating CysLTR1 (C/C) genotype. Lane 5 and 8: Show three bands of 150, 97 and 53 bp indicating CysLTR1 (C/T) genotype

\subsection{Amplification}

Amplification was made by the same method described above. The oligonucleotide primers were, forward 5' CTC TCC TAT ATT TCT TTT CTG C 3' and reverse 5' CTA TAC TTT ACA TAT TTC TTC TCC 3'(New England Biolabs Inc., USA). PCR conditions For CysLTR1 $927 T / C$ were, 5 min for initial denaturation at $94^{\circ} \mathrm{C} ; 30$ cycles at $94^{\circ} \mathrm{C}$ for $30 \mathrm{sec}$ for denaturation, $30 \mathrm{sec}$ at $59^{\circ} \mathrm{C}$ for annealing and $1 \mathrm{~min}$ at $72^{\circ} \mathrm{C}$ for extension, followed by $10 \mathrm{~min}$ at $72^{\circ} \mathrm{C}$ for final extension (Lee et al., 2007).

\subsection{Restriction Fragment Length Polymorphism}

After amplification, PCR products were digested by the restriction endonuclease Hpyl88I (New
England Biolabs). The following components were in $20 \mu \mathrm{L}$ tube reaction, $5 \mu \mathrm{L}$ of pyrogen free water, $2 \mu \mathrm{L}$ of $10 \mathrm{X}$ reaction buffer, $3 \mu \mathrm{L}$ of the restriction enzyme containing $10 \mathrm{U}$ of the enzyme and $10 \mu \mathrm{L}$ PCR products. The components were mixed gently, spin down briefly and then incubated at $37^{\circ} \mathrm{C}$ for $4 \mathrm{~h}$.

\subsection{Detection}

The Digestion products were analyzed on $2 \%$ agarose gel stained with ethidium bromide solution $\left(1 \mathrm{mg} \mathrm{mL}^{-1}\right)$. The results of the digestion were as follow, a single undigested band of $150 \mathrm{bp}$ for $T$ allele, 2 bands of $97 \mathrm{bp}$ and 53 for $C$ allele and 3 bands of 150, 97 and 53 for heterozygous person (Fig. 2). 
Ethics approval: The Ethics Committee at the Faculty of Medicine, Zagazig University approved this study.

\subsection{Statistical Analysis}

The data were collected, presented and analyzed using SPSS-PC (version 10) software. Comparisons between groups were done using student $t$ test and Mann Whitney test. Also, qualitative categories were expressed in the form of frequency and percentage, comparisons between categories were done by Chi square test and ANOVA, while. The test results were considered significant when $P$. value $<0.05$, while, the test results were considered non-significant when $\mathrm{P}$ value $>0.05$.

\section{RESULTS}

In this study the most common allergen causing positive skin test among asthmatic patients was pollen $(66.6 \%)$ and the lowest one was wool $(3 \%)$. The mean values of total serum IgE levels of asthmatic patients
(340.4 $\pm 214 \mathrm{IU} / \mathrm{mL})$ were higher than that of the control group $(35.6 \pm 21.2 \mathrm{IU} / \mathrm{mL}) \quad(\mathrm{p}<0.001)$. There was no relation between age of onset of asthma and total serum IgE levels in patients $(p>0.05)$. The mean values of urinary leukotriene E4 levels in patient group $(111 \pm 46.6$ $\mathrm{pg} / \mathrm{mg}$ creatinine) were higher than its levels in control group $(22.4 \pm 25.4 \mathrm{pg} / \mathrm{mg}$ creatinine) $(\mathrm{p}<0.001)$ (These data are not presented).

The distribution of LTC4S-444 A/C genotypes in patients and healthy controls was statistically insignificant $(\mathrm{p}=0.52)$ (Table 1). The frequency of $A$ allele was $85 \%$ in controls, $76.7 \%$ in asthmatic patients, while $\mathrm{C}$ allele frequency was $15 \%$ in controls, $23.3 \%$ in asthmatic patients (Table 2). There was a significant differences in urinary leukotriene E4 levels according to LTC $4 S-444 A / C$ promoter polymorphism in asthmatics (p<0.001), the patients with genotypes $A C$ and $C C$ were high producers of Cys-LTs compared to $A A$ genotype (Table 3). There was no relation between age of onset of asthma and different genotypes of $L T C 4 S-444$.

Table 1. Genotyping frequency of LTC4 S (-444 A/C) among patient and control groups

\begin{tabular}{|c|c|c|c|c|}
\hline & \multicolumn{2}{|c|}{ Control group $(\mathrm{n}=30)$} & \multicolumn{2}{|c|}{ Patient group $(n=30)$} \\
\hline & No & $\%$ & No & $\%$ \\
\hline$\overline{A A}$ & 23 & 76.7 & 19 & 63.3 \\
\hline$A C$ & 5 & 16.7 & 8 & 26.7 \\
\hline$C C$ & 2 & $\begin{array}{l}6.7 \\
X^{2}=1.27 \\
P=0.52\end{array}$ & 3 & 10.0 \\
\hline
\end{tabular}

Table 2. Alleles frequency of LTC4 S (-444 A/C) among patient and control groups

\begin{tabular}{|c|c|c|c|c|c|}
\hline & \multicolumn{2}{|c|}{ Control group $(\mathrm{n}=30)$} & \multicolumn{2}{|c|}{ Patient group $(\mathrm{n}=30)$} & \multirow{2}{*}{$\begin{array}{l}(\mathrm{OR}) \mathrm{CI} 95 \% \\
1.72(0.63-4.82)\end{array}$} \\
\hline & No & $\%$ & No & $\%$ & \\
\hline$A$ allele & 51 & 85.0 & 46 & 76.7 & \\
\hline$C$ allele & $\begin{array}{l}9 \\
X^{2}= \\
P=\end{array}$ & 15.0 & 14 & 23.3 & \\
\hline
\end{tabular}

Table 3. Relationship between genotypes of LTC4 synthase (-444 A/C) and leukotriene E4 level among asthmatic patients

\begin{tabular}{llllll}
\hline Urinary LTE4 Pg/mg & $A A$ & $A C$ & $C C$ & $\mathrm{f}$ & $\mathrm{p}$ \\
\hline Range & $28-132$ & $114-180$ & $140-188$ & 18.6 & $<0.001$ \\
Mean \pm SD & $84.8 \pm 33.7$ & $151.7 \pm 25.7$ & $169.3 \pm 25.7$ & & \\
\hline
\end{tabular}

Table 4. Genotyping frequency of CysLTR1 (972 T/C) among males in patient and control groups

\begin{tabular}{|c|c|c|c|c|}
\hline \multirow[b]{2}{*}{ Males } & \multicolumn{2}{|c|}{ Control group $(n=13)$} & \multicolumn{2}{|c|}{ Patient group $(n=15)$} \\
\hline & No & $\%$ & No & $\%$ \\
\hline $\bar{T}$ & 9 & 69.2 & 8 & 53.3 \\
\hline$C$ & $\begin{array}{l}4 \\
X^{2}=0.74 \\
P=0.31\end{array}$ & 30.8 & 7 & 46.7 \\
\hline
\end{tabular}


Heba M. Kadry et al. / American Journal of Immunology 10 (2): 63-72, 2014

Table 5. Genotyping frequency of CysLTR1 (972 T/C) among females in patient and control groups

\begin{tabular}{|c|c|c|c|c|}
\hline \multirow[b]{2}{*}{ Females } & \multicolumn{2}{|c|}{ Control group $(n=17)$} & \multicolumn{2}{|c|}{ Patient group $(n=15)$} \\
\hline & No & $\%$ & No & $\%$ \\
\hline$T T$ & 10 & 58.8 & 5 & 33.3 \\
\hline$T C$ & 5 & 29.4 & 7 & 46.6 \\
\hline$C C$ & $\begin{array}{l}2 \\
X^{2}= \\
P=\end{array}$ & 11.7 & 3 & 20.0 \\
\hline
\end{tabular}

Table 6. Alleles frequency for of Cys LTR1 $(927 T / C)$ in patient and control groups.

\begin{tabular}{|c|c|c|c|c|c|}
\hline \multirow[b]{2}{*}{ Males } & \multicolumn{2}{|c|}{ Control group $(n=30)$} & \multicolumn{2}{|c|}{ Patient group $(n=30)$} & \multirow{2}{*}{$\begin{array}{l}\text { (OR) CI 95\% } \\
1.97(0.32-12.5)\end{array}$} \\
\hline & No & $\%$ & No & $\%$ & \\
\hline$T$ allele & 9 & 69.2 & 8 & 53.3 & \\
\hline$C$ allele & $\begin{array}{l}4 \\
X^{2}= \\
P=\end{array}$ & 30.8 & 7 & 46.7 & \\
\hline \multicolumn{6}{|l|}{ Females } \\
\hline $\begin{array}{l}T \text { allele } \\
(0.66-6.95)\end{array}$ & 25 & 73.5 & 17 & 56.7 & 2.12 \\
\hline$C$ allele & $\begin{array}{l}9 \\
X^{2}= \\
P=\end{array}$ & 26.4 & 13 & 43.3 & \\
\hline
\end{tabular}

Table 7. Genetic combination of LTC4 S (-444 A/C) and CysLTR1 (927 T/C) among males in patient and control groups

\begin{tabular}{|c|c|c|c|c|c|c|c|c|c|}
\hline \multirow[b]{2}{*}{ Genotypes } & \multicolumn{2}{|c|}{ Controls } & \multicolumn{2}{|c|}{ Patients } & \multirow[b]{2}{*}{ Alleles } & \multicolumn{2}{|c|}{ Controls } & \multicolumn{2}{|c|}{ Patients } \\
\hline & No & $\%$ & No & $\%$ & & No & $\%$ & No & $\%$ \\
\hline$\overline{T / A A}$ & 6 & 46.1 & 5 & 33.3 & $T / A$ & 8 & 50.0 & 7 & 33.3 \\
\hline$T / A C$ & 2 & 15.0 & 2 & 13.3 & $T / C$ & 4 & 25.0 & 3 & 14.3 \\
\hline$T / C C$ & 2 & 15.0 & 1 & 6.6 & $C / A$ & 3 & 18.7 & 6 & 28.5 \\
\hline$C / A A$ & 2 & 15.0 & 2 & 13.3 & $C / C$ & 1 & 6.3 .0 & 5 & 23.8 \\
\hline$C / A C$ & 1 & 7.0 & 4 & 26.6 & $X^{2}=3.26$ & & & & \\
\hline \multirow[t]{3}{*}{$C / C C$} & 0 & 0.0 & 1 & 6.6 & $\mathrm{P}=0.35$ & & & & \\
\hline & \multicolumn{9}{|c|}{$X^{2}=3.1$} \\
\hline & \multicolumn{9}{|c|}{$P=0.68$} \\
\hline
\end{tabular}

Table 8. Genetic combination of LTC4S (-444 A/C) and CysLTR1 (927 T/C) among females in patient and control groups

\begin{tabular}{|c|c|c|c|c|c|c|c|c|c|}
\hline \multirow[b]{2}{*}{ Genotypes } & \multicolumn{2}{|c|}{ Controls } & \multicolumn{2}{|c|}{ Patients } & \multirow[b]{2}{*}{ Alelles } & \multicolumn{2}{|c|}{ Control } & \multicolumn{2}{|c|}{ Patients } \\
\hline & No & $\%$ & No & $\%$ & & No & $\%$ & No & $\%$ \\
\hline TT/AA & 9 & 52.9 & 4 & 26.6 & $T / A$ & 13 & 61.9 & 10 & 52.6 \\
\hline$T T / A C$ & 0 & 0 & 1 & 6.6 & $T / C$ & 5 & 23.8 & 2 & 10.5 \\
\hline$T T / C C$ & 0 & 0 & 0 & 0.0 & $C / A$ & 1 & 4.7 & 4 & 21.2 \\
\hline$T C / A A$ & 5 & 29.4 & 5 & 33.3 & $C / C$ & 2 & 9.5 & 3 & 15.8 \\
\hline$T C / A C$ & 1 & 5.9 & 1 & 6.6 & $X^{2}=3.59$ & & & & \\
\hline$T C / C C$ & 0 & 0 & 1 & 6.6 & $\mathrm{P}=0.3$ & & & & \\
\hline$C C / A A$ & 2 & 11.7 & 3 & 20.0 & & & & & \\
\hline$C C / A C$ & 0 & 0 & 0 & 0.0 & & & & & \\
\hline$C C / C C$ & 0 & $\begin{array}{l}0 \\
X^{2}=4.01 \\
P=0.54\end{array}$ & 0 & 0.0 & & & & & \\
\hline
\end{tabular}

As regard CysLTRl $927 T / C$ polymorphism the results for male and female subjects were calculated

separately because of genetic location of CysLTRl gene in chromosome X. The distribution of CysLTR1 927 T/C 
genotypes in patient group and healthy controls was statistically insignificant either in males or females $(\mathrm{p}=$ $0.31, \mathrm{p}=0.35$ ) respectively (Table 4 and 5).

In males, the frequency of $T$ allele was $69.2 \%$ in control group, $53.3 \%$ in asthmatic patients, while $C$ allele frequency was $30.8 \%$ in controls, $46.7 \%$ in asthmatic patients. While in females, the frequency of $T$ allele was $73.5 \%$ in control group, $56.7 \%$ in asthmatic patients, while $C$ allele frequency was $26.4 \%$ in controls, $43.3 \%$ in asthmatic patients (Table 6).

Association analysis for both genotypes and alleles combination revealed no significant difference between the two groups either in males or females (Table 7 and 8 ).

\section{DISCUSSION}

Cysteinyl leukotrienes have been shown to have important roles in asthma. They promote inflammation processes including eosinophil migration, increase in vascular permeability and bronchoconstriction (Devi et al., 2012). In this study the most common allergens causing positive skin test among asthmatic patients were pollen $(63.41 \%)$, smoke $(53.65 \%)$, hay dust $(48.78 \%)$ and house dust (40\%). Our results were in agree with (Al-Azzazy et al., 2008; Shabrawy, 2011; Hassan, 2013).

In our study the mean values of total serum IgE levels of asthmatic patients $(340.4 \pm 214 \mathrm{IU} / \mathrm{mL})$ were higher than that of the control group $(35.6 \pm 21.2 \mathrm{IU} / \mathrm{mL})$ $(\mathrm{p}<0.001)$.This was in agree with (Kohi and Choi, 2002) and Maité et al. (2011), they found that, total serum IgE was increased in asthmatics patients compared to controls. However other study by Bettiol et al. (2000) did not find a difference in IgE concentration between controls and atopic asthmatic patiens. One explanation is that atopic patients who show low serum IgE levels seem to have high tissue sensitivity even to these low levels and to react with these low concentration of the antibody (Wüthrich and Schmid-Grendelmeier, 2003). In the present study, there was no correlation between total serum IgE levels and age of onset of asthma. This result was in agreement with (El-Hossary, 2002; Al-Azzazy et al., 2008).

The mean value of urinary LTE4 levels in this study was higher in asthmatic patients $(221.5 \pm 15.9 \mathrm{pg} / \mathrm{mg}$ creatinine) than in the healthy controls $(78.5 \pm 10.2 \mathrm{pg} / \mathrm{mg}$ creatinine). This result was in agree with studies done by Gaki et al. (2007) and Abdel Fattah et al. (2012) they found that, urinary LTE4 levels were increased in asthmatic patients compared to controls.

Bronchial asthma is a multigenic disease, where both genetic and environmental factors have important roles in pathogenesis. Many genes interact to produce the final clinical phenotype (Michael et al., 2013).

In the present study, we analyzed two different polymorphisms in two genes that are implicated in the action of leukotrienes, LTC4S-444 A/C and CysLTR1 927 $A / T$. Consequently, we decided to analyze the effects of the allelic and genomic combinations of both polymorphisms because it has been suggested that although most identified polymorphisms have a small influence on multifunctional diseases, combinations of genetic polymorphisms have larger functional effects than individual variants and thus might better explain susceptibility to asthma.

$L T C 4 S$ is one of the enzymes responsible for the synthesis of cysteinyl LTs. The-444A/C polymorphism was identified in the LTC4S gene promoter region. An association between the polymorphic-444C allele and susceptibility to asthma has been described (Sampson et al., 2000). The LTC4S-444 A/C SNP was a good study candidate due to its position within the promoter, its location in the chromosome $5 \mathrm{q} 35$ region (in close proximity to a region consistently associated with asthma) and its creation of an additional transcription factor-binding site (Niegowski et al., 2014).

Regarding LTC4S (-444 A/C) genotype difference, this study did not show any statistical difference in neither genotypes distribution or alleles frequencies between the two studied groups. However $A A$ genotype was presented more in control group $(76.7 \%)$ than in patient group $(63.3 \%)$.

Our results were in agreement with studies done by Moissidis et al. (2005) and Jung et al. (2009), they found that $A A$ genotype was presented more in control subjects than in patients but the difference in genotypes distribution did not reach statistical difference. Other results by and Kang et al. (2011) and Ingrid et al. (2012) also failed to prove such association.

On the other hand, Sampson et al. (2000) showed increased prevalence of the variant LTC4 synthase genotypes $C C$ and $C A$ in the patients with asthma (56\%) compared with the normal subjects $(32 \%)$ and his results were statically significant. In a meta-analysis study made by Yonggang et al. (2012), they found a significant association between LTC4S and risk of asthma in Caucasians $(\mathrm{p}=0.03)$ but not in Asian $(\mathrm{p}=0.66)$ and African-Americans.

Difference in the studies results may be due to that several genes might be involved in susceptibility and their interactions might be so varied and might be dependent on a unique profile of the disease alleles for each population. Consequently, identification of asthma 
susceptible genes in one population might be hard to reproduce in another population.

In this study there was a significant difference in mean urinary leukotriene E4 levels in patients with $C C$ genotype $(169.3 \pm 25.7 \mathrm{pg} / \mathrm{mg})$ and $A C$ genotype $(151.7 \pm 25.7 \mathrm{pg} / \mathrm{mg}$ ) compared to patients with $A A$ genotype $(84.8 \pm 33.7 \mathrm{pg} / \mathrm{mg})$. This was in agreement with (Szczeklik and Stevenson, 1999; Sampson et al., 2000).

Opposing to this finding, Lima et al. (2006) and Joelene et al. (2009). did not find difference between LTC $4 S-444 A / C$ genotypes and urinary LTE4 levels in asthmatic patients.

In this study there was no significant difference between different genotypes of LTC4S and age of onset of asthma. This was in agreement with a studies done by (Kawagishi et al., 2002; Pan et al., 2006; Mary-Anne et al., 2004). On the other hand, Wu et al. (2008) found that the asthmatics with the $C(-444)$ allele were younger than the asthmatics with $A A$ with earlier onset age and longer duration of disease compared to those with $A A$ (both $\mathrm{p}<0.05$ ).

In the present study, due to the genetic location of the CysLTR1 gene in chromosome X, we separately analyzed the male and female populations and obtained different results in both groups.

Regarding genotype frequency of CysLTR1 there was no statistical difference between patient and control groups in genotypes frequency either for males of females. However the frequency of $C$ genotypes was higher in male patients $(46.6 \%)$ than in male controls $(30.8 \%)$. The same observation was found in females, the frequency of both $T C$ and $C C$ were higher in patients (46.4 and $20 \%$ respectively) than the controls (29.4 and $11.7 \%)$.

In agreement with this, Jung et al. (2009) and Joelene et al. (2009), did not found any relation between different genotypes frequency and asthma phenotypes. Two separate studies in a Japanese population support this result and found no association of the $927 \mathrm{SNP}$ in CysLTRl with asthma (Unoki et al., 2000; Zhang et al., 2006).

However other studies supported the important role of this polymorphism in asthma, Sanz et al. (2006) found that there was a statistical significant difference in genotypes distribution, among male patients, the frequency of $C$ genotype was $12 \%$ while in control group $C$ genotype was $2 \%$. While there was no difference among females. This was in agreement with Hong et al. (2009).

Regarding alleles frequency of CysLTR1, in this study there was no statistical difference in alleles between the two studied groups in either males or females. However $C$ allele was present more in patient group (46\% for males \& $43.3 \%$ for females) than in control group (30.8\% for males \& $26.4 \%$ for females). This was in agreement with a studies done by (Hao et al., 2006; Arriba-Méndeza et al., 2008).

In a study of Sanz et al. (2006), they found a clear differences in the alleles distribution between genders. These differences are due to the fact that males provide only one copy of the X chromosome. Therefore, they are effectively haploid for that chromosome. Thus, haploid phenotype reflects the presence of whatever allele is present. In the group of male individuals, they found that the $C$ allele of 927T/C CysLTRl was more common among male patients with asthma $(23 \%)$ than controls $(8 \%)$, while in females, there were no differences in $C$ allele distribution between patients with asthma (23\%) and controls (22\%).

In the present study we did not find any association between CysLTR1 variations and age of onset of asthma in either males or females, this result was in agreement with Joelene et al. (2009).

In the present study in order to investigative the effect of the polymorphism of the two loci on asthma development further association analysis for both genotypes and alleles combinations was carried out.

Regarding males the overall distribution of both genotypes and alleles did not show any statistical difference between the studied groups $(\mathrm{p}=0.68$ and $\mathrm{p}=$ 0.35 ). However, $T / A A$ combination was presented in controls more frequent than patients $(46.1 \%$ versus $33.3 \%$ ) and that $C / A C$ combination was presented more frequently in patient group than control group (26.6\% versus $7 \%$ ). Also the $C / C$ alleles combination was present in patients $(23.8 \%)$ more than control group $(6.3 \%)$. The same results was almost found in females, the overall distribution of both genotypes and alleles did not show a statistical difference between the studied groups ( $\mathrm{p}=0.54$ and 0.3 ). TT/AA combination was presented in controls more frequent than patients $(52.9 \%$ versus $26.6 \%$ ) and that the $C / A$ and $C / C$ alleles combination was present in patients more frequently than control group. This was in agreement with studies by Jung et al. (2009) and Joelene et al. (2009). they found that $L T C 4 S A / C$ and CysLTRI T/C polymorphisms and their gene-gene interactions did not associated with asthma phenotype. However Sanz et al. (2006) and Arriba-Méndeza et al. (2008) detected differences in the distribution of 927T/C CysLTR1/-444A/C LTC4S combinations between the group of patients with asthma and the group of controls especially in male patients. The 
combination of both the $T$ allele of $927 T / C$ CysLTR1 and the $A$ allele of $-444 A / C$ LTC $4 S$ was slightly more common in controls than in patients with asthma.

\section{CONCLUSION}

In conclusion the current investigation does not support an important role for either $L T C 4 S-444 A / C$ and CysLTR1 $927 T / C$ nor their gene-gene interaction in development of asthma in our studied population. However a slight increase in mutant genotypes versus the wild one were observed in asthmatic patients. Leukotriene levels were increased in asthmatic patients compared to controls and polymorphism of LTC4 gene may influence the magnitude of CysLTs production.

However. Such evidence does not preclude the likelihood that polymorphism in these genes may predict those asthmatic individuals in whom leukotrienes make a relatively large pathophysiological contribution. A limitation of our study is the relatively small sample size studied, therefore, we believe that our findings may stimulate further studies on larger number of Egyptian patients.

\section{RECOMMENDATION}

Because of the heterogeneous nature of asthma, these association studies need to be replicated in a number of cohorts of different ethnic backgrounds with asthma of different severity.

\section{REFERENCES}

Abdel Fattah, M., E. Nehal and S. Nadia, 2012. Urinary levels of leukotriene E4 in acute asthmatic children. J. Pediatr. Sci., 4: 134-39.

AL-Azzazy, E., B. Mervat, M. Soliman and H. Kadry, 2008. Urinary leukotriene level in patients with bronchial asthma. Egypt. J. Med. Microbiol., 17: 135-143.

Arriba-Méndeza, S., C. Sanzb and M. Isidoro-Garcaac, 2008. Analysis of $927 T>C$ CYSLTR1 and $-444 A>$ $C$ LTC4S polymorphisms in children with asthma. Allergol et Immunopathol., 36: 259-63. DOI: 10.1016/S0301-0546(08)75220-0

Austen, K.F., A. Maekawa, Y. Kanaoka and J.A. Boyce 2009. The leukotriene E4 puzzle: Finding the missing pieces and revealing the pathobiologic implications. J. Allergy Clin. Immunol., 124: 40614. PMID: 19647860
Bettiol, J., P. Bartsch and R. Louis, 2000. Cytokine production from peripheral whole blood in atopic and non-atopic asthmatics, relationship with blood and sputum eosinophilia and serum IgE levels. Europ. J. Allergy Clin. Immunol., 55: 1134-41.DOI: 10.1034/j.1398-9995.2000.00711.x

Celine, N., F. Elisabeth and M. Joanne, 2012. Human Th2 cells respond to cysteinyl leukotrienes through selective expression of cysteinyl leukotriene receptor 1. J. Allergy Clin. Immunol., 129: 1136-42. DOI: $10.1016 /$ j.jaci.2012.01.057

Niegowski, D., T. Kleinschmidt, U. Olsson, S. Ahmad and A. Rinaldo-Matthis et al., 2014. Crystal structures of leukotriene $\mathrm{C} 4$ synthase in complex with product analogs: Implications for the enzyme mechanism. J. Biol. Chem., 289: 199-207. PMID: 24366866

Devi, S., D. Nisha and A. Mukesh, 2012. Leukotriene C4 synthase: Upcoming drug target for inflammation. Current Drug Targets, 13: 1114-25. DOI: 10.2174/138945012802009053

Duroudier, N.P., D.P. Strachan, J.D. Blakey and I.P. Hall, 2009. Association of the cysteinyl leukotriene receptor 1 gene with atopy in the British 1958 birth cohort. J. Allergy Clin. Immunol., 124: 566-572. PMID: 19733299

El-Hossary, D., 2002. Circulating level of Interleukin-6 and Interleukin-6 receptor in patients with bronchial asthma. M.Sc. Thesis, Microbiology and Immunology Department Faculty of Medicine, Zagazig University.

Gaki, E., G. Papatheodorou and E. Ischaki, 2007. Leukotriene E4 in urine in patients with asthma and COPD. Respiratory Med., 101: 826-32. DOI: 10.1016/j.rmed.2006.06.031

GINA, 2011. National Heart Lung and Blood Institute. Global strategy for asthma management and prevention updated.

Hao, L., I. Sayers and J. Cakebread, 2006. The cysteinylleukotriene type 1 receptor polymorphism $927 \mathrm{~T} / \mathrm{C}$ is associated with atopy severity but not with asthma. Clin. Exp. Allergy, 36: 735-41. DOI: 10.1111/j.1365-2222.2006.02511.x

Hassan, S., 2013. Tumor necrosis factor gene polymorphism in patients with bronchial asthma. M.D. Thesis, Microbiology and Immunology Department, Faculty of Medicine, Zagazig University. 
Hiromichi, S., U. Yoko, H. Ago, D. Irikura and A. Nisawa et al., 2011. The catalytic architecture of Leukotriene C4 Synthase with Two Arginine Residues. J. Biol. Chem., 286: 16392-401. DOI: 10.1074/jbc.M110.150177, PMID: 21454538

Hong, X., H. Zhou and H. Tsai, 2009. Cysteinyl leukotriene receptor 1 gene variation and risk of asthma. Eur. Respir J., 33: 42-8. DOI: 10.1183/09031936.00057708

Ingrid, Q., D. Juan, G. Jenny and F. Mercedes, 2012. The Leukotriene C4 Synthase (A-444C) Promoter Polymorphism in Venezuelan Individuals with Asthma. World Allergy Organ. J., 5: 125.

Jenna, R. and M. Clare, 2010. Chronic inflammation and asthma. Mutat. Res., 690: 24-39. DOI: 10.1016/j.mrfmmm.2009.09.005

Joelene, B., S. Khoo and G. Zhang, 2009. Leukotriene pathway polymorphisms are associated with altered cysteinyl leukotriene production in children with acute asthma. Prostaglandins Leukot Essent Fatty Acids, 81: 9-15. DOI: 10.1016/j.plefa.2009.05.022

Jung, Y., J. Byung and H. Young, 2009. Association study of polymorphism in leukotriene C4 synthase and cysteinyl leukotriene receptor 1 genes with phenotype of asthma and clinical parameters in Korean children. Korean J. Pediatr., 52: 680-8. DOI: 10.3345/kjp.2009.52.6.680

Kang, M., J. Kwon and B. Kim, 2011. Polymorphisms of the PTGDR and LTC4S influence responsiveness to leukotriene receptor antagonists in Korean children with asthma. J. Hum. Genet, 56: 284-9. DOI: 10.1038/jhg.2011.3

Okunishi, K. and M. Peters-Golden, 2011. Leukotrienes and airway inflammation. Bioch. Biophys. Acta, 1810: 1096-102. DOI: 10.1016/j.bbagen.2011.02.005

Kawagishi, Y., H. Mita and M. Taniguchi, 2002. Leukotriene C4 synthase promoter polymorphism in Japanese patients with aspirin-induced asthma. J. Allergy Clin Immunol., 109: 936-42. DOI: 10.1067/mai.2002.124466

Kohi, Y. and I. Choi, 2002. Blood eosinophil counts for the prediction of the severity of exercise-induced bronchospasm in asthma. Respiratory Med., 96: 120-5. DOI: 10.1053/rmed.2001.1238

Lee, Y., B. Kimw and H. Kimz, 2007. Responsiveness to montelukast is associated with bronchial hyperresponsiveness and total immunoglobulin $\mathrm{E}$ but not polymorphisms in the leukotriene $\mathrm{C} 4$ synthase and cysteinyl leukotriene receptor 1 genes in Korean children with Exercise-Induced Asthma (EIA). Clin. Exp. Allergy, 37: 1487-93. DOI: 10.1111/j.1365-2222.2007.02795.x
Lima, J., S. Zhang and A. Grant, 2006. Influence of leukotriene pathway polymorphisms on response to montelukast in asthma. Am. J. Respir. Crit. Care Med., 173: 379-85. DOI: 10.1164/rccm.200509-1412OC

Maité, M., H. Gabriele and S. Florence, 2011. Assessment of Total immunoglobulin E (tIgE) and cytokines in asthma according to disease severity. Insights Lung Disease Using Novel Methods.

Mary-Anne, K., S. Jing and D. David, 2004. Characterization of two polymorphisms in the leukotriene C4 synthase gene in an Australian population of subjects with mild, moderate and severe asthma. J. Allergy Clin. Immunol., 113: 88995. DOI: 10.1016/j.jaci.2004.02.008

Michael, E, M. Patrick and H. Hakon, 2013. Genetic polymorphisms and associated susceptibility to asthma. Int. J. General Med.., 6: 253-265.

Moissidis, I., B. Chinoy and K. Yanamandra, 2005. Association of IL-13, RANTES and leukotriene C4 synthase gene promoter polymorphisms with asthma and/or atopy in African Americans. Genet Med., 7: 406-10. DOI: 10.1097/01.GIM.0000170994.24960.48

Pan, M., S. Tie-ying and Z. Hong-sheng, 2006. Association between leukotriene C4 synthase A444C polymorphism and asthma in Chinese Han population in Beijing. Chin Med. J., 119: 1834-8.

Sampson, A.P., S. Siddiqui and D. Buchanan, 2000. Variant LTC4 synthase allele modifies cysteinyl leukotriene synthesis in eosinophils and predicts clinical response to zafirlukast. Thorax, 55: 28-31. DOI: 10.1136/thorax.55.suppl_2.S28

Sanz, C., M. Isidro-Garcia and I. Dvila, 2006. Analysis of 927T/C CysLTR1 and -444A/C LTC4S polymorphisms in patients with asthma. J. Investig Allergol Clin Immunol., 16: 331-7.

Shabrawy, S., 2011. IL-18 gene polymorphism in patients with bronchial asthma. M.D. Thesis, Microbiology and Immunology Department, Faculty of Medicine, Zagazig University.

Szczeklik, A. and D. Stevenson, 1999. Aspirin-induced asthma: Advances in pathogenesis and management. J. Allergy Clin. Immunol., 104: 5-13. DOI: 10.1016/S0091-6749(99)70106-5

Unoki, M., F. Sachiyo and O. Yoshihiro, 2000. Association studies of 33 Single Nucleotide Polymorphisms (SNPs) in 29 candidate genes for bronchial asthma: Positive association of a T924C polymorphism in the thromboxane A2 receptor gene. Human Genetic, 106: 440-6. DOI: $10.1007 / \mathrm{s} 004390000267$ 
Wu, Y., C. Liu and K. Wang, 2008. The relevance of leukotriene C 4 synthase gene A (-444) C polymorphism to clinical responsiveness to montelukast in patients with asthma. Zhonghua Jie He He Hu Xi Za Zhi., 31: 806-10.

Wüthrich, B. and P. Schmid-Grendelmeier, 2003. The atopic eczema/dermatitis syndrome. Epidemiology, natural course and immunology of the IgEassociated ("extrinsic") and the nonallergic ("intrinsic") AEDS. J. Investigational Allergol. Clin. Immunol., 3: 1-5.
Yonggang, Z., H. Honglang and H. Jichong, 2012. The 444A/C Polymorphism in the LTC4S gene and risk of asthma: Meta-analysis. Arch Med. Res., 43: 44450. DOI: 10.1016/j.arcmed.2012.08.003

Zhang, J., O. Migita and M. Koga, 2006. Determination of structure and transcriptional regulation of CysLTR1 and an association study with asthma and rhinitis. Pediatr Allergy Immunol., 17: 242-9. DOI: 10.1111/j.1399-3038.2005.00347.x 